\title{
PERAN BRAND IMAGE MEMEDIASI PROMOSI DAN HARGA TERHADAP KEPUTUSAN PEMBELIAN SMARTPHONE SAMSUNG DI KOTA DENPASAR
}

\author{
Astari Armayani ${ }^{1}$ \\ I Made Jatra ${ }^{2}$ \\ ${ }^{1}$ Fakultas Ekonomi dan Bisnis Universitas Udayana, Bali, Indonesia \\ e-mail: astariprinting@gmail.com
}

\begin{abstract}
ABSTRAK
Sasaran dari penelitian ini bertujuan guna untuk memberikan penjelasan mengenai pengaruh brand image terhadap keputusan pembelian, promosi terhadap keputusan pembelian, harga terhadap keputusan pembelian. Metode yang digunakan untuk menentukan sampel adalah non-probability berbentuk purposive sampling dengan ukuran sampel sebanyan 112 orang responden. Pengumpulan data dilakukan dengan penyebaran kuisioner secara langsung dan melalui online pada pelanggan produk smartphone Samsung di Kota Denpasar. Teknik analisis yang digunakan adalah analisis jalur (path analysis) dan uji sobel. Hasil pengujian dari promosi dan harga secara positif dan signifikan berpengaruh terhadap brand image dan keputusan pembelian produk smartphone Samsung di Kota Denpasar. Brand image mampu memediasi pengaruh promosi dan harga secara positif dan signifikan terhadap keputusan pembelian. Hal ini menunjukan bahwa brand image memiliki peranan penting pada promosi dan harga konsumen sehingga meningkatkan keputusan pembelian produk smartphone Samsung di Kota Denpasar. Manajemen perusahaan Samsung sebaiknya lebih gecar melakukan marketing mix sehingga konsumen semakin mempercayai kinerja-kinerja yang dilakukan perusahaan Samsung.

Kata kunci : brand image, promosi, harga dan keputusan pembelian
\end{abstract}

\begin{abstract}
The purpose of this study is to provide an explanation of the influence of brand image on purchasing decisions, promotion of purchasing decisions, prices on purchasing decisions.The method used to determine the sample is non-probability in the form of purposive sampling with a sample size of 112 respondents. Data collection is done by distributing questionnaires directly and through online to Samsung smartphone product customers in Denpasar City. The analysis technique used is path analysis (path analysis) and sobel test. The test results from promotions and prices positively and significantly influence the brand image and decision to purchase Samsung smartphone products in the city of Denpasar. Brand image is able to mediate the influence of promotions and prices positively and significantly on purchasing decisions. This shows that the brand image has an important role in the promotion and consumer prices, thus increasing the decision to buy Samsung smartphone products in the city of Denpasar. The management of Samsung companies should be more aggressively conducting marketing mix so that consumers increasingly trust the performance of the Samsung company.

Keywords: brand image, promotion, price and purchasing decision
\end{abstract}




\section{PENDAHULUAN}

Perkembangan media teknologi komunikasi di Indonesia ini semakin canggih, seperti semakin banyaknya masyarakat yang menggunakan media komunikasi. Perkembangan teknologi komunikasi ini tidak lepas dari semakin kompleks kegiatan manusia saat ini. Semakin kompleksnya kegiatan manusia mendorong semakin beragam kebutuhan yang diperlukan. Kebutuhan tersebut berdampak pada meningkatnya permintaan akan berbagai jenis alat komunikasi yang mengakibatkan semakin banyaknya persaingan dalam dunia bisnis dibidang telekomunikasi. Industri telekomunikasi memunculkan berbagai perangkat yang mendukung tergesernya tablet, komputer dan telepon genggam standar dengan hadirnya sebuah perangkat yang memudahkan pekerjaan manusia yaitu telepon pintar atau sering dikenal juga dengan smartphone.

Sejalan dengan perkembangan waktu, smartphone mengalami banyak perubahan, misalnya pada perkembangan waktu, smartphone yang dulunya sebagian besar digunakan untuk menerima telpon dan SMS (Short Messaging Service) berkembang menjadi Video Call. Kemudian saat ini dengan semakin majunya teknologi komunikasi membuat penambahan fitur-fitur baru yang mendukung kegunaan dari smartphone itu sendiri seperti beberapa aplikasi media sosial yaitu: Facebook, Twitter, Line, dan media sosial lainnya yang berkembang di seluruh dunia termasuk di Indonesia (Dharma dan Sukaatmadja, 2015).

Beberapa fenomena yang sangat hangat diperbincangkan adalah bagaimana setiap orang di seluruh dunia sangat terobsesi dan kecanduan akan smartphone. Bahkan kecanduan akan smartphone bukan hanya menyerang orang dewasa tetapi juga anak-anak. Dalam kehidupan di jaman sekarang dapat dilihat bahwa masyarakat bahkan lebih mementingkan smartphone dibandingkan bersosialisasi dengan teman-teman atau kerabat yang ada di lingkungan sekitarnya. Smartphone seakan sudah menjadi teman terdekat bahkan dapat membuat seseorang lupa waktu jika telah memainkan smartphone-nya. Salah satu strategi yang dapat digunakan oleh produsen smartphone adalah meningkatkan keputusan pembelian konsumen melalui promosi dan menyesuaikan harga merupakan strategi produsen dalam menarik perhatian para konsumen.

Sebuah perusahaan dalam mengeluarkan produk harus disesuaikan dengan kebutuhan dan keinginan konsumen, sehingga konsumen memiliki alternatif pilihan produk sebelum mengambil keputusan untuk membeli produk yang ditawarkan. Memahami faktor-faktor psikologis dan pribadi konsumen sangatlah penting dan kemungkinan memilki pengaruh yang kuat terhadap perilaku pembelian serta pengingatan merek pada jasa, produk, dan perusahaan Afroz, (2013). Keputusan pembelian menurut Schiffman dalam Sumarwan (2004:289) adalah suatu keputusan sebagai pemilihan dalam mengambil suatu tindakan dari dua atau lebih pilihan alternatif.

Brand image berperan sebagai faktor mediasi antara variabel promosi dan harga dengan keputusan pembelian. Merek merupakan nama, istilah, tanda, simbol, atau rancangan, atau kombinasi hal-hal tersebut, yang dimaksudkan untuk mengidentifikasi barang atau jasa dari seorang atau sekelompok penjual dan untuk membedakannya dari produk pesaing Kotler (1998). Menurut 
American Marketing Association (AMA) dalam Kotler, (2003) merek (brand) yaitu nama, istilah,tanda, simbol, atau desain atau paduan dari hal - hal tersebut yang dimaksudkan untuk memberikan identitas bagi barang atau jasa yang dibuat atau disediakan suatu penjual atau kelompok penjual serta membedakannya dari barang atau jasa yang disediakan pesaing.

Perusahaan dapat mengkomunikasikan produk kepada konsumen melalui program - program promosi di antaranya periklanan, promosi penjualan, penjualan pribadi, publisitas, pemasaran langsung. Dengan promosi, keunggulan yang dimiliki sebuah produk dapat diketahui oleh konsumen dan bisa membuat konsumen tertarik untuk mencoba dan kemudian akan mengambil keputusan untuk membeli produk tersebut. Penerapan program promosi yang tepat, akan meningkatkan kepercayaan pelanggan kepada perusahaan pada giliranya akan meningkatkan hasil penjualan (Lestari, 2012).

Menurut Alma (2006) promosi adalah sejenis komunikasi yang memberikan penjelasan dan meyakinkan calon konsumen mengenai barang dan jasa dengan tujuan untuk memperoleh perhatian, mendidik, mengingatkan dan meyakinkan calon konsumen. Klarisa (2012) menyatakan promosi merupakan salah satu faktor penentu keberhasilan program pemasaran atau strategi pemasaran. Salah satu strategi yang digunakan oleh produsen smartphone untuk meningkatkan keputusan pembelian sebuah produk adalah melalui promosi dan harga produk.

Harga merupakan salah satu faktor penentu pembeli dalam menentukan suatu keputusan pembelian terhadap suatu produk maupun jasa. Apalagi apabila produk atau jasa yang akan dibeli tersebut merupakan kebutuhan sehari-hari seperti makanan, minuman dan kebutuhan pokok lainnya, pembeli akan sangat memperhatikan harganya menurut Ghanimata dan Kamal (2012).

Menurut Satit et al. (2012), harga adalah salah satu unsur bauran pemasaran yang mempengaruhi keputusan pembelian pelanggan, sebagai hasil dari penelitiannya, penjual bisa mempertahankan pelanggan setia dengan menawarkan harga yang menarik dan kompetitif, dan memberikan potongan harga yang spesial. Agusty Ferdinand dalam Dinawan (2010), harga merupakan salah satu variabel penting dalam pemasaran, dimana harga dapat mempengaruhi konsumen dalam mengambil keputusan untuk membeli suatu produk, karena berbagai alasan.

Banyaknya perusahaan telepon seluler pintar atau smartphone di Indonesia tetap memunculkan satu nama yang memiliki market share terbesar, yaitu Samsung terlihat pada Tabel 1 .

Tabel 1.

Market Share Smartphone Tahun 2016 di Indonesia

\begin{tabular}{cccccccc}
\hline Periode & Samsung & Apple & $\begin{array}{c}\text { Huawei } \\
\mathbf{( \% )}\end{array}$ & OPPO & Vivo & Lainnya & Total \\
\hline 2016Q1 & 23,8 & 15,4 & 8,4 & 5,9 & 4,4 & 42,1 & 100 \\
$2016 \mathrm{Q} 2$ & 22,7 & 11,7 & 9,3 & 6,6 & 4,8 & 44,9 & 100 \\
2016Q3 & 20,9 & 12,5 & 9,3 & 7,1 & 5,9 & 44,3 & 100 \\
2016Q4 & 18,0 & 18,2 & 10,5 & 7,3 & 5,7 & 40,3 & 100 \\
2017Q1 & 23,3 & 14,7 & 10,0 & 7,5 & 5,5 & 39,0 & 100 \\
\hline \multicolumn{7}{l}{ Sumber: IDC (International Data Corpuration), 2017}
\end{tabular}


Tabel 1. menunjukkan bahwa smartphone Samsung selalu memiliki market share tertinggi dibandingkan pesaingnya. Pada fase kuartil pertama tahun 2016 (2016Q1) Samsung memiliki market share sebesar 23,8 \% dari total pasar, pada kuartil ke dua tahun 2016 (2016Q2) mengalami penurunan menjadi

Sebesar 22,7 \%, pada kuartil ke tiga pada tahun yang sama (2016Q3) mengalami penurunan menjadi sebesar $20,9 \%$ dan kembali menurun pada kuartil ke empat ditahun yang sama (2016Q4) menjadi sebesar 18,0 \%. Meski tahun 2016 market share smartphone Samsung terus mengalami penurunan, tetapi Samsung tetap memiliki market share tertinggi dibandingkan dengan smartphone lainnya.

Market share Samsung mengalami peningkatan pada kuartil pertama tahun 2017 (2017Q1) menjadi sebesar 23,3 \%, Meskipun Samsung memiliki market share terbesar di pasar, tetapi tidak menjamin produk tersebut tidak luput dari kesalahan. Fenomena yang terjadi belakangan ini berbagai tipe smartphone keluaran Samsung mengalami permasalahan yang merugikan konsumen penggunanya. Berdasarkan laman liputan6.com berbagai tipe Samsung meledak di berbagai belahan dunia salah satunya di Indonesia. Permasalahan yang ada pada smartphone Samsung ini tentu akan berpengaruh terhadap brand image, promosi, harga serta keputusan pembelian. Kejadian tersebut cenderung dapat membuat penjualan smartphone Samsung mengalami penurunan, namun berdasarkan survei top brand award 2017 fase 1 menunjukkan hasil yang berbeda pada Tabel 2.

Tabel 2.

Top Brand Index Kategori Telekomunikasi Smartphone pada tahun 2017

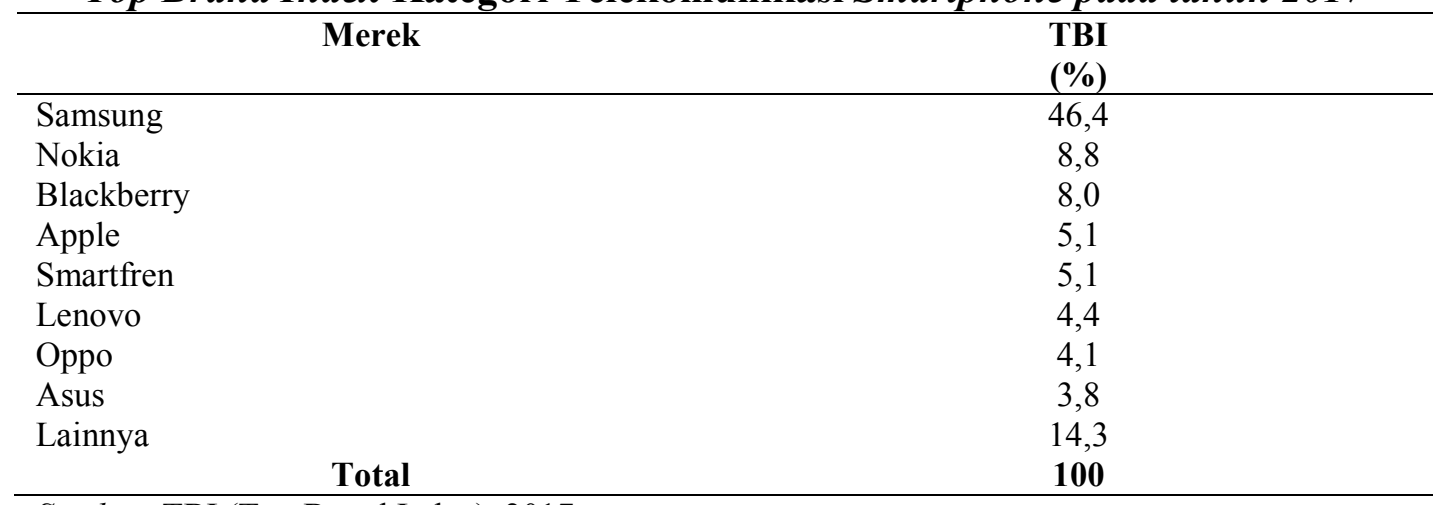

Sumber: TBI (Top Brand Index), 2017

Berdasarkan Tabel 2. menunjukkan bahwa smartphone Samsung tetap menjadi primadona di mata konsumen meskipun telah mengalami beberapa masalah. Setiap perusahaan akan selalu berusaha untuk mempertahankan dan menjaga keunggulan brand image yang dimilikinya, karena umumnya sering konsumen mengansumsikan brand image yang baik dengan kualitas produk itu sendiri (Amanah, 2011). Dalam kebutuhan penggunaan suatu produk, konsumen telah menganggap brand image sebagai sebuah prestise. Artinya konsumen akan memiliki citra yang lebih tinggi jika menggunakan produk dengan brand image yang baik. Brand image yang selama ini dimiliki oleh smartphone Samsung dimata konsumen adalah baik. Brand image yang positif mempunyai pengaruh yang positif pada keputusan pembelian, semakin tinggi brand image yang 
diciptakan oleh perusahaan maka tingkat pengambilan keputusan untuk membeli juga semakin meingkat (Suciningtyas, 2012). Jadi, kegunaan dari programprogram promosi yang dilakukan perusahaan adalah selain memberikan infromasi kepada konsumen juga untuk membangun citra yang positif terhadap suatu merek. Brand image juga membantuk konsumen dalam menentukan pilihan terhadap produk/jasa yang diinginkan. Perusahaan harus mampu menciptakan brand image yang baik agar suatu produk yang ditawarkan akan sukses di pasaran (Fristiana, 2012).

Penelitian mengenai pengaruh harga tehadap keputusan pembelian sudah pernah dilakukan sebelumnya, salah satunya adalah Zhafira et al. (2013) dimana hasil penelitian ini menyatakan bahwa harga sebagai salah satu faktor yang memiliki pengaruh signifikan terhadap keputusan pembelian konsumen. Bertolak belakang pada penelitian Widianto (2009) menyatakan bahwa harga tidak memiliki pengaruh yang signifikan terhadap keputusan pembelian. Purnamasari dan Murwatiningsih (2015) menyatakan bahwa harga tidak memiliki pengaruh yang signifikan terhadap keputusan pembelian konsumen. Bertolak belakang dengan hasil yang didapat oleh Ghanimata dan Kamal (2012) menyatakan harga mempunyai pengaruh yang signifikan dan positif terhadap keputusan pembelian dengan Thitung pada variable harga (X1) adalah sebesar 2,318 dengan tingkat signifikan 0,023. Ranto (2014) mendapatkan hasil penelitian, citra merek tidak berpengaruh terhadap keputusan pembelian pada produk UKM di Yogyakarta.

Penelitian yang dilakukan oleh Widianto, Toni Eko (2009) dengan judul penelitian "Analisis Pengaruh Faktor-Faktor Marketing mix Terhadap Keputusan Pembelian Kompor Geni di Sidoarjo' didapatkan hasil bahwa Promosi negatif dan tidak berpengaruh signifikan terhadap keputusan pembelian. Selain promosi, faktor yang juga sangat penting dalam mempengaruhi keputusan pembelian individu adalah harga. Harga merupakan salah satu elemen yang cukup penting dalam menentukan pangsa pasar dan keuntungan suatu perusahaan serta merupakan faktor yang mempengaruhi pilihan para pembeli.

Berdasarkan hasil pra survei yang dilakukan terhadap 25 orang di Kota Denpasar dapat dijelaskan bahwa dari 25 orang yang peneliti survei, 23 orang mengetahui produk smartphone Samsung dan 2 orang tidak mengetahui produk tumbler Starbucks sehingga tidak dapat melanjutkan menjawab pertanyaan. Sebanyak 25 orang yang mengetahui produk smarthphone Samsung, 23 orang mengatakan sudah pernah melakukan pembelian smartphone Samsung dan berniat untuk membeli kembali smartphone Samsung. Berdasarkan pra survei, 23 orang berniat melakukan pembelian smartphone Samsung karena brand image yang dimiliki smartphone Samsung cukup baik, promosi smartphone Samsung juga banyak, harga dari produk smartphone Samsung terjangkau sehingga dapat memutuskan konsumen untuk membeli produk smartphone Samsung. Karena peneliti ingin meneliti bagaimana pengaruh variabel bebas promosi dan harga memeberikan pengaruh terhadap variabel keputusan pembelian serta brand image sebagai variabel mediasi.

Menurut (Tjiptono, 2005) Promosi merupakan upaya untuk mengarahkab seseorang agar dapat mengenal produk perusahaan, memahaminya, merubah sikap, menyukai, yakin, akhinya melakukan dan selalu ingat akan produk tersebut 
dibenaknya. Margiyanto (2013) menyatakan bahwa semakin sering suatu produk dipromosikan maka tidak menutup kemungkinan produk tersebut akan mendorong para konsumen untuk mencoba. Menurut penelitian oleh Marnis dan Marzdina (2010) yang meneliti mengenai pengaruh promosi terhadap brand image Rokok Lucky Strike di Kota Pekan Baru menyatakan bahwa promosi berpengaruh terhadap brand image. Berdasarkan hasil-hasil penelitian terdahulu yang memperoleh hasil positif maka dapat disusun hipotesis sebagai berikut :

$\mathrm{H}_{1}$ : Promosi berpengaruh positif dan signifikan terhadap brand image

Dahmiri (2009) dalam penelitianya menyatakan bahwa harga berpengaruh signifikan terhadap citra Ramayana Department Store. Penelitian tersebut sejalan dengan penelitian yang dilakukan oleh Noerchoidah (2013) yang mendapatkan hasil bahwa harga dapat mempengaruhi secara signifikan terhadap Brand Image. Begitupula yang dilakukan oleh Falihah (2013) menyatakan bahwa harga berpengaruh secara signifikan terhadap citra merek. Berdasarkan hasil-hasil penelitian terdahulu yang memperoleh hasil positif maka dapat disusun hipotesis sebagai berikut :

$\mathrm{H}_{2}$ : Harga berpengaruh positif dan signifikan terhadap Brand Image

Hasan (2013:215-217) mengatakan bahwa sebuah merek yang kuat akan memudahkan konsumen untuk mengevaluasi, menimbang dan membuat keputusan membeli dari semua rincian nilai-nilai yang terkait dengan kinerja produk, harga, pengiriman. Mendrofa (2010), penelitianya menyatakan bahwa brand image secara umum memiliki pengaruh positif terhadap keputusan pembelian.

Fristiana, dkk (2012) dalam penelitianya menyatakan bahwa citra merek terhadap keputusan pembelian berpengaruh positif dan signifikan, artinya apabila harga semakin murah maka keputusan pembelian juga akan meningkat, begitu pula sebaliknya Heriyati dan Septi (2013) dalam penelitianya menyatakan bahwa terdapat pengaruh yang signifikan antara variable brand image (X1) terhadap variable keputusan pembelian (Y) konsumen pad handphone Nexian. Malik et al. (2013), Musay (2013) Mendapatkan hasil yang sama dengan yang menyatakan bahwa brand image berpengaruh signifikan terhadap keputusan pembelian. Berdasarkan hasil-hasil penelitian terdahulu yang memperoleh hasil positif maka dapat disusun hipotesis sebagai berikut:

$\mathrm{H}_{3}$ : Brand Image berpengaruh positif dan signifikan tehadap keputusan Pembelian.

Tjiptono (2009:91) menerangkan bahwa promosi merupakan suatu komunikasi pemasaran, yaitu aktifitas pemasaran yang berusaha untuk menyebarkan informasi, mempengaruhi atau membujuk, dan atau mengingatkan pasar sasaran atas perusahaan dan produknya agar bersedia menerima, membeli dan loyal pada produk yang ditawarkan perusahaan yang bersangkutan. Modi (2012) menyatakan bahwa unsur-unsur promosi merupakan kombinasi yang relevan sebagai alat yang efektif dan memiliki implikasi yang besar terhadap keputusan pembelian. Penelitian yang dilakukan oleh Mirabi et al. (2015) 
menemukan bahwa terdapat hubungan yang positif dan signifikan antara promosi dengan keputusan pembelian. Berdasarkan hasil-hasil penelitian terdahulu yang memperoleh hasil positif maka dapat disusun hipotesis sebagai berikut :

$\mathrm{H}_{4}$ : Terdapat hubungan yang positif dan signifikan antara promosi dengan keputusan pembelian

Menurut Asri dalam Susanto (2013) penilaian harga dapat memberikan pengaruh yang besar bagi konsumen untuk memilih produk tertentu maupun toko atau penjual tertentu. Dalam penelitian Purnawati menyatakan bahwa variable harga mempunyai pengaruh yang signifikan dan positif terhadap keputusan pembelian. Begitu pula dengan penelitian yang dilakukan oleh Mongi, dkk (2013) dan Komalasari (2013) dalam penelitianya menyatakan bahwa harga mempunyai pengaruh signifikan dan positif terhadap keputusan pembelian. Berdasarkan hasilhasil penelitian terdahulu yang memperoleh hasil positif maka dapat disusun hipotesis sebagai berikut:

$\mathrm{H}_{5}$ : Harga berpengaruh positif dan signifikan terhadap keputusan pembelian

Kegiatan- kegiatan dalam mempromosikan produk dan membangun citra merek yang baik di benak konsumen diharapkan efektif dalam meningkatkan penjualan perusahaan. Penelitian yang dilakukan Evelina dkk (2012) menyatakan bahwa variabel promosi dan citra merek bersama-sama mempengaruhi keputusan pembelian kartu perdana Telkomflexi dimana saat konsumen melakukan pembelianya melihat variable promosi dan citra merek yang ada supaya pada saat membeli produk tersebut mendapatkan manfaatnya. Penelitian yang dilakukan oleh Purnamasari (2015) yang meneliti mengenai brand image sebagai mediasi pengaruh promosi, harga dan sikap konsumen terhadap loyalitas konsumen jamu Nyonya Meneer di Semarang menyatakan bahwa promosi berpengaruh terhadap loyalitas konsumen melalui brand image. Artinya brand image dapat memediasi pengaruh promosi terhadap loyalitas konsumen. Berdasarkan penelitian tersebut, dapat ditarik hipotesis.

$\mathrm{H}_{6}$ : Peran brand Image memediasi pengaruh promosi terhadap keputusan Pembelian

Pada penelitian yang di lakukan oleh Noerchoidah (2013) menyatakan bahwa harga berpengaruh terhadap brand image yang kemudian mempengaruhi keputusan pembelian. Penelitian yang di lakukan oleh Fianto (2014) mendapatka hasil analisis menunjukan bahwa citra merk memiliki pengaruh positif dan signifikan terhadap perilaku membeli di kalangan mahasiswa di tiga belas perguruan tinggi islam swasta di Jawa Timur Indonesia.

Purnamasari dan Murwatiningsih (2015) dalam penelitianya menunjukan bahwa harga berpengaruh langsung terhadap keputusan pembelian melalui brand image. Hal ini menunjukan bahwa brand image merupakan jalur untuk meningkatkan keputusan pembelian pada pengaruh harga terhadap keputusan pembelian. Berdasarka paparan penelitian di atas, diperoleh hipotesis sebagai berikut : 
$\mathrm{H}_{7}$ : Peran brand Image memediasi pengaruh harga terhadap keputusan Pembelian

\section{METODE PENELITIAN}

Penelitian ini dilakukan di daerah Kota Denpasar, yang mencakup daerah Denpasar Utara, Denpasar Timur, Denpasar Selatan, dan Denpasar Barat. Pemilihan Kota Denpasar adalah karena melihat komposisi dari masyarakatnya yang heterogen berasal dari berbagai daerah lain di Provinsi Bali, sehingga secara tidak langsung, penelitian yang dilakukan ini dapat mewakili seluruh masyarakat yang ada di Provinsi Bali.

Populasi dalam penelitian ini adalah konsumen Samsung Kota Denpasar dengan jumlah populasi yang tidak diketahui secara pasti (infinite). Ukuran sampel yang baik adalah 5 - 10 kali jumlah variabel atau indikator dalam penelitian. Penelitian ini menggunakan 16 indikator sehingga dengan menggunakan estimasi jumlah minimal responden sebanyak 80 orang dan maksimal 160 orang. Karena keterbatasan peneliti, maka peneliti sendiri menggunakan sampel sebanyak 112 responden.

Teknik analisis data yang digunakan dalam penelitian ini adalah analisis jalur (path analysis).

Hipotesis : Promosi $\left(\mathrm{X}_{1}\right)$ dan Harga $\left(\mathrm{X}_{2}\right)$ berpengaruh terhadap Brand image $(\mathrm{M})$

Struktur : $M=\beta_{1} X+\beta_{2} X+e_{1}$

Hipotesis :Promosi $\left(\mathrm{X}_{1}\right)$, Harga $\left(\mathrm{X}_{2}\right)$, berpengaruh terhadap Keputusan Pembelian (Y)

Struktur : $Y=\beta_{3} X_{1}+\beta_{4} X_{2}+\beta_{5} M+e 2$

Keterangan:

\begin{tabular}{|c|c|}
\hline $\mathrm{X}$ & $=$ celebrity endorser \\
\hline $\mathrm{Y}_{1}$ & $=$ brand image \\
\hline $\mathrm{Y}_{2}$ & $=$ purchase intention \\
\hline $\begin{array}{l}\beta_{1}, \beta_{2}, \beta_{3} \\
\mathrm{e}\end{array}$ & $\begin{array}{l}=\text { koefisien regresi variabel } \\
=\text { error }\end{array}$ \\
\hline
\end{tabular}

\section{HASIL DAN PEMBAHASAN}

Karakteristik responden disajikan secara umum berdasarkan beberapa kriteria sampel yang telah ditentunkan yaitu produk smartphone Samsung yang di pakai, jenis kelamin, umur pekerjaan, dan pendidikan. Jumlah responden dalam penelitian ini yaitu 112 responden.

Tabel 4 memperlihatkan karakteristik penelitian ini sebagian besar konsumen berjenis perempuan sebanyak 80 orang ( 71 persen) bila dibandingkan dengan persentase responden yang berjenis kelamin laki - laki hanya sebanyak 32 orang (28 persen). Hal ini berarti lebih banyaknya pembeli perempuan yang memiliki ketertarikan terhadap adanya variasi harga serta lebih mudah tertarik dengan adanya promosi - promosi yang dilakukan produk Smartphone Samsung. 
Tabel 4.

Karakteristik Responden

\begin{tabular}{|c|c|c|c|c|}
\hline No & Kriteria & Klasifikasi & $\begin{array}{l}\text { Jumlah } \\
\text { (Orang) }\end{array}$ & $\begin{array}{c}\text { Persentas } \\
(\%) \\
\end{array}$ \\
\hline \multirow[t]{3}{*}{1} & Jenis kelamin & Laki-laki & 32 & 28 \\
\hline & & Perempuan & 80 & 71 \\
\hline & Jumlah & & 112 & 100 \\
\hline \multirow[t]{5}{*}{2} & Umur & 17-26 tahun & 78 & 69 \\
\hline & & 27-36 tahun & 27 & 24 \\
\hline & & $37-46$ tahun & 5 & 4 \\
\hline & & $\geq 47$ tahun & 2 & 1 \\
\hline & Jumlah & & 112 & 100 \\
\hline \multirow[t]{5}{*}{3} & Pekerjaan/ Status & PNS & 5 & 4 \\
\hline & & Wiraswasta & 5 & 4 \\
\hline & & Mahasiswa & 92 & 82 \\
\hline & & Karyawan Swasta & 10 & 8 \\
\hline & Jumlah & & 112 & 100 \\
\hline \multirow[t]{4}{*}{4} & Pendidikan Terakhir & SMA & 90 & 80 \\
\hline & & Diploma & 4 & 3 \\
\hline & & Sarjana & 18 & 16 \\
\hline & Jumlah & & 112 & 100 \\
\hline
\end{tabular}

Sumber: Data diolah, 2018

Selanjutnya bila dilihat dari usia responden mayoritas responden berusia 17 - 26 tahun yakni sebesar 78 orang (69 persen), kemudian diikuti dengan kelompok usia $>26-36$ tahun sebesar 27 orang ( 24 persen), selanjutnya kelompok usia $>36-46$ tahun sebesar 5 orang ( 4 persen) dan terakhir kelompok usia $\geq 47$ tahun. Perbedaan yang cukup signifikan tersebut dikarenakan pembeli pada usia 17 - 26 tahun memiliki ketertarikan terhadap produk smartphone pada usia tersebut karena seseorang cenderung menggunakan smartphone sebagai gaya hidup dan prestise.

Klasifikasi selanjutnya yakni klasifikasi pekerjaan, yang dalam penelitian ini didominasi oleh klasifikasi Mahasiswa yakni sebesar 92 orang (82 persen), kemudian karyawan swasta sebesar 10 orang (8 persen), klasifikasi PNS dan wiraswasta masing - maisng sebesar 5 orang (4 persen). Hal ini menunjukkan bahwa target utama dari smartphone Samsung adalah Mahasiswa dikarenakan kebutuhan aplikasi yang kompleks dan hal itu dapat dipenuhi oleh produk smartphone Samsung.

Klasifikasi terakhir yakni klasifikasi pendidikan terakhir, yang dalam penelitian ini dibagi menjadi tiga jenjang pendidikan diantaranya klasifikasi tingkat SMA yang mendominasi yakni sebesar 90 orang (80persen), kemudian klasifikasi Sarjana sebesar 18 orang (16 persen), dan terakhir klasifikasi Diploma sebesar 4 orang (3 persen).

Uji validitas bertujuan untuk memeriksa apakah kuesioner sebagai instrument penelitian sudah tepat untuk mengukur indikator dalam penelitian. Hasil uji validitas instrument penelitian disajikan dalam tabel 5 yang menunjukan bahwa seluruh indikator pernyataan dalam variable promosi dan harga, brand image dan keputusan pembelian produk smartphone Samsung di Kota Denpasar. 
Memiliki korelasi item total lebih besar atau sama dengan 0,30 sehingga seluruh indikator tersebut telah memenuhi syarat validitas data.

Tabel 5.

Hasil Uji Validitas Instrumen

\begin{tabular}{ccccc}
\hline No & Variabel & Item Pernyataan & Korelasi Item Total & Keterangan \\
\hline \multirow{4}{*}{1} & & $\mathrm{X}_{1.1}$ & 0.723 & Valid \\
& & $\mathrm{X}_{1.2}$ & 0.915 & Valid \\
& $\left(\mathrm{X}_{1}\right)$ & $\mathrm{X}_{1.3}$ & 0.757 & Valid \\
& & $\mathrm{X}_{1.4}$ & 0.743 & Valid \\
& & $\mathrm{X}_{1.1}$ & 0.864 & Valid \\
& Harga & $\mathrm{X}_{1.2}$ & 0.818 & Valid \\
& $\left(\mathrm{X}_{2}\right)$ & $\mathrm{X}_{1.3}$ & 0.680 & Valid \\
& & $\mathrm{X}_{1.4}$ & 0.652 & Valid \\
& & $\mathrm{M}_{1.1}$ & 0.871 & Valid \\
3 & Brand Image (M) & $\mathrm{M}_{1.2}$ & 0.922 & Valid \\
& & $\mathrm{M}_{1.3}$ & 0.918 & Valid \\
& & $\mathrm{M}_{1.4}$ & 0.842 & Valid \\
& & $\mathrm{Y}_{1.1}$ & 0.806 & Valid \\
4 & Keputusan Pembelian & $\mathrm{Y}_{1.2}$ & 0.831 & Valid \\
& & $\mathrm{Y}_{1.3}$ & 0.914 & Valid \\
& & $\mathrm{Y}_{1.4}$ & 0.869 & Valid
\end{tabular}

Sumber: Data diolah, 2018

Hasil ujji validitas yang ditampilkan pada Tabel 5 menunjukan bahwa 16 indikator yang digunakan memiliki korelaso diatas 0,3 yaitu dari nilai korelasi yang terkecil sebesar 0.652 hingga nilai korelasi terbesar sebesar 0.918 sehingga keseluruhan indikator yang digunakan dinyatakan valid dan dapat dilanjutkan ke analisa berikutnya.

Hasil uji relabilitas instrument penelitian untuk menetapkan apakah instrument kuisioner dapat digunakan lebih dari satu kali, dengan responden yang sama disajikan Tabel 6 . yang menunjukan bahwa ketiga instrument penelitian yaitu variabel promosi, harga, brand image dan keputusan pembelian produk smartphone Samsung di Kota Denpasar memiliki koefisien cronbach's alpha > 0,60 sehingga pernyataan pada kuisioner tersebut reliabel.

Tabel 6.

Hasil Uji Reliabilitas Instrument

\begin{tabular}{cccc}
\hline No & Variabel & Cronbach's Alpha & Keterangan \\
\hline 1 & Promosi $\left(\mathrm{X}_{1}\right)$ & 0.793 & Reliabel \\
2 & Harga $\left(\mathrm{X}_{2}\right)$ & 0.737 & Reliabel \\
3 & Brand Image $(\mathrm{M})$ & 0.907 & Reliabel \\
4 & Keputusan Pembelian $(Y)$ & 0.872 & Reliabel \\
\hline
\end{tabular}

Sumber: Data diolah, 2018

Hasil uji reliabilitas yang ditampilkan Tabel 6. menunjukan seluruh instrument penelitian dikatakan reliabel dimana keseluruhan instrument layak digunakan untuk mengumpulkan data. Nilai keseluruhan alpha cronbach $>0,6$ menunjukan bahwa pengukuran tersebut dapat memberikan hasil yang konsisten apabila dilakukan pengukuran kembali terhadap subyek yang sama pada waktu yang berbeda. 
Menyusun persamaan struktural yang akan digunkan, maka data yang diperoleh harus diolah dan dihitung terlebih dahulu dengan menggunkan program SPSS. Data yang telah diolah dan dihitung akan menunjukkan hasil analisis seperti berikut.

Hasil Analisis Jalur Persamaan Regresi 1

$$
\begin{array}{llll}
\mathrm{X} 1 & =0,412 \mathrm{X} 1+0,446 \mathrm{X} 2 & & \\
\mathrm{~S}(\beta) & =(0,84),(0,83) & & \\
\mathrm{t} & =(4,994),(5,398) & & \\
\mathrm{Sig} & =(0,000),(0,000) & & \\
\mathrm{R}^{2} & =0,629 \quad \mathrm{df}=109 & \mathrm{~F}=92,582 & \mathrm{Sig}=0,000
\end{array}
$$

Hasil perhitungan F menunjukkan angka sebesar 92,582, dengan signifikansi sebesar 0,000. Angka tersebut jauh lebih kecil dari level of significant 5 persen yang biasa digunakan dalam penelitian ekonomi. Ini berarti bahwa variabel promosi dan harga $(\mathrm{X})$ berpengaruh terhadap brand image $(\mathrm{M})$.

Nilai $\beta_{1}$ adalah sebesar 0,412 memiliki arti promosi berpengaruh positif terhadap brand image, dengan kata lain jika faktor promosi meningkat maka brand image akan meningkat sebesar 0,412. Nilai $\beta_{2}$ adalah sebesar 0,446 memiliki arti harga berpengaruh positif terhadap brand image, dengan kata lain jika harga meningkat maka brand image akan meningkat pula.

Hasil Analisis Jalur Persamaan Regresi 2 dapat dijelaskan sebagai berikut:

$$
\begin{array}{llll}
\hat{Y} & =0,289 X 1+0,337 X 2+0,339 M & \\
\mathrm{~S}(\beta) & =(0,076)(0,076)(0,78) & & \\
\mathrm{t} & =(3,927)(4,500)(4,398) & & \\
\mathrm{Sig} & =(0,000)(0,000)(0,000) & & \\
\mathrm{R}^{2} & =0,762 \quad \mathrm{df}=108 & \mathrm{~F}=115,293 & \mathrm{Sig}=0,000
\end{array}
$$

Hasil perhitungan F menunjukkan angka sebesar 115,293, dengan signifikansi sebesar 0,000. Angka tersebut jauh lebih kecil dari level of significant 5 persen yang biasa digunakan dalam penelitian ekonomi. Ini berarti bahwa secara serempak variabel promosi dan harga $(\mathrm{X})$ dan brand image $(\mathrm{M})$ berpengaruh serempak terhadap keputusan pembelian (Y).

Nilai $\beta_{3}$ adalah sebesar 0,289 memiliki arti bahwa promosi berpengaruh positif terhadap keputusan pembelian, dengan kata lain jika promosi meningkat, maka keputusan pembelian akan meningkat sebesar 0,289.

Nilai $\beta_{4}$ adalah sebesar 0,337 memiliki arti bahwa harga berpengaruh positif signifikan terhadap keputusan pembelian, dengan kata lain jika harga meningkat, keputusan pembelian akan meningkat sebesar 0,337 . Nilai $\beta_{5}$ adalah sebesar 0,339 memiliki arti bahwa brand image berpengaruh positif terhadap keputusan pembelian, dengan kata lain jika brand image meningkat, keputusan pembelian akan meningkat sebesar 0,339 .

Perhitungan pengaruh variabel promosi $\left(\mathrm{X}_{1}\right)$ terhadap keputusan pembelian $(\mathrm{Y})$ melalui brand image $(\mathrm{M})$ yaitu:

indirect effect $=\beta 1 \times \beta 5 \ldots \ldots \ldots \ldots \ldots \ldots \ldots \ldots$ (3)

$$
=0,412 \times 0,339
$$




$$
=0,140
$$

pengaruh variabel harga $\left(\mathrm{X}_{2}\right)$ terhadap keputusan pembelian $(\mathrm{Y})$ melalui brand image $(\mathrm{M})$ yaitu:

$$
\begin{aligned}
\text { Indirect effect } & =\beta 2 \times \beta 5 \\
& =0,446 \times 0,339 \\
& =0,151
\end{aligned}
$$

Pehitungan total pengaruh variabel promosi $\left(\mathrm{X}_{1}\right)$ terhadap keputusan pembelian melalui brand image $(\mathrm{M})$ yaitu:

$$
\begin{aligned}
\text { total effect } & =\beta_{3}+\left(\beta_{1} \times \beta_{5}\right) \ldots \ldots \ldots \ldots \ldots \\
& =0,289+(0,412 \times 0,339) \\
& =0,430
\end{aligned}
$$

Perhitungan total pengaruh variabel harga $\left(\mathrm{X}_{2}\right)$ terhadap keputusan pembelian melalui brand image $(\mathrm{M})$ yaitu:

$$
\begin{aligned}
\text { total effect } & =\beta_{4}+\left(\beta_{2} \times \beta_{5}\right) \ldots \ldots \ldots \ldots \\
& =0,337+(0,446 \times 0,339) \\
& =0,337+(0,151) \\
& =0,488
\end{aligned}
$$

Berdasarkan model substruktur 1 dan model substruktur 2, maka dapat disusun model diagram jalur akhir. Sebelum menyusun model diagram jalur akhir, terlebih dahulu dihitung nilai standar error sebagai berikut:

$$
\begin{aligned}
& \mathrm{e}=\sqrt{1-R^{2}} \ldots \ldots \ldots \ldots \ldots \ldots \ldots \ldots \\
& \mathrm{e}_{1}=\sqrt{1-R 1^{2}}=\sqrt{1-0,629}=0,609 \\
& \mathrm{e}_{2}=\sqrt{1-R 2^{2}}=\sqrt{1-0,762}=0,487
\end{aligned}
$$

Berdasarkan perhitungan pengaruh error (e), didapatkan hasil pengaruh error $\left(\mathrm{e}_{1}\right)$ sebesar 0,609 dan pengaruh error $\left(\mathrm{e}_{2}\right)$ sebesar 0,488 .

Hasil koefisien determinasi total adalah sebagai berikut:

$$
\begin{aligned}
\mathrm{R}^{2} \mathrm{~m} & =1-\left(\mathrm{Pe}_{1}\right)^{2}\left(\mathrm{Pe}_{2}\right)^{2 \ldots \ldots \ldots \ldots . . .} \\
& =1-(0,609)^{2}(0,488)^{2} \\
& =1-(0,371)(0,238) \\
& =1-0,088 \\
& =0,912
\end{aligned}
$$

Nilai determinasi total sebesar 0,912 mempunyai arti bahwa sebesar 91,2 persen variasi keputusan pembelian dipengaruhi oleh variasi promosi, harga dan variasi brand image, sementara sisanya sebesar 8,8 persen dijelaskan oleh faktor lain yang tidak dimasukkan ke dalam model. 
Berdasarkan hasil pengujian Sig. F dihasilkan Sig. $F \leq 0,05(0,000 \leq 0,05)$ maka $\mathrm{H}_{1}$ diterima yaitu promosi, harga dan brand image berpengaruh secara signifikan terhadap keputusan pembelian. Kesimpulanya adalah bahwa model persamaan structural telah memenuhi syarat goodness of fit melalui uji $\mathrm{F}$.

Berdasarkan hasil analisis pengaruh pengaruh promosi terhadap brand image diperoleh nilai Sig t sebesar 0,000 dengan nilai koefisien beta sebesar 0,412 Nilai Sig. t $0,000 \leq 0,05$ mengindikasikan bahwa $\mathrm{H}_{0}$ ditolak dan $\mathrm{H}_{1}$ diterima. Hasil ini mempunyai arti bahwa promosi berpengaruh positif dan signifikan terhadap brand image.

Berdasarkan hasil analisis pengaruh pengaruh harga terhadap brand image diperoleh nilai Sig t sebesar 0,000 dengan nilai koefisien beta sebesar 0,446 Nilai Sig. t $0,000 \leq 0,05$ mengindikasikan bahwa $\mathrm{H}_{0}$ ditolak dan $\mathrm{H}_{1}$ diterima. Hasil ini mempunyai arti bahwa harga berpengaruh positif dan signifikan terhadap brand image.

Berdasarkan hasil analisis pengaruh pengaruh promosi terhadap keputusan pembelian diperoleh nilai Sig t sebesar 0,000 dengan nilai koefisien beta sebesar 0,289 Nilai Sig. t $0,000 \leq 0,05$ mengindikasikan bahwa $\mathrm{H}_{0}$ ditolak dan $\mathrm{H}_{1}$ diterima. Hasil ini mempunyai arti bahwa promosi berpengaruh positif dan signifikan terhadap keputusan pembelian.

Berdasarkan hasil analisis pengaruh pengaruh harga terhadap keputusan pembelian diperoleh nilai Sig t sebesar 0,000 dengan nilai koefisien beta sebesar 0,337 Nilai Sig. t $0,000 \leq 0,05$ mengindikasikan bahwa $\mathrm{H}_{0}$ ditolak dan $\mathrm{H}_{1}$ diterima. Hasil ini mempunyai arti bahwa harga berpengaruh positif dan signifikan terhadap keputusan pembelian.

Berdasarkan hasil analisis pengaruh pengaruh brand image terhadap keputusan pembelian diperoleh nilai Sig t sebesar 0,000 dengan nilai koefisien beta sebesar 0,339 Nilai Sig. t 0,000 $\leq 0,05$ mengindikasikan bahwa $\mathrm{H}_{0}$ ditolak dan $\mathrm{H}_{1}$ diterima. Hasil ini mempunyai arti bahwa brand image berpengaruh positif dan signifikan terhadap keputusan pembelian.

Tabel 7.

Pengaruh Langsung, Pengaruh Tidak Langsung serta Pengaruh Total Promosi dan Harga (X), Brand Image (M), dan Keputusan Pembelian (Y)

\begin{tabular}{cccc}
\hline $\begin{array}{c}\text { Pengaruh } \\
\text { Variabel }\end{array}$ & $\begin{array}{c}\text { Pengaruh } \\
\text { Langsung }\end{array}$ & $\begin{array}{c}\text { Pengaruh Tidak Langsung } \\
\text { Melalui Brand Image }\end{array}$ & Pengaruh Total \\
\hline $\mathrm{X}_{1} \longrightarrow \mathrm{M}$ & 0,412 & - & 0,412 \\
$\mathrm{X}_{2} \longrightarrow \mathrm{M}$ & 0,446 & - & 0.446 \\
$\mathrm{X}_{1} \longrightarrow \mathrm{Y}$ & 0,289 & 0,119 & 0,408 \\
$\mathrm{X}_{2} \longrightarrow \mathrm{Y}$ & 0,337 & 0,150 & 0,487 \\
$\mathrm{M} \longrightarrow \mathrm{Y}$ & 0,339 & - & 0,339 \\
\hline
\end{tabular}

Sumber: Data diolah, 2018

Hasil pada tabel 7. menunjukan bahwa pengaruh langsung variabel promosi terhadap keputusan pembelian memiliki nilai koefisien beta sebesar 0,289 namun pengaruh tidak langsung yang dimediasi oleh brand image menunjukan nilai koefisien beta sebesar 0,119 dengan pengaruh total sebesar 0,408. Selain itu,itu, pengaruh langsung harga terhadap keputusan pembelian memiliki nilai koefisien 
beta sebesar 0,337, namun pengaruh tidak langsung yang dimediasi oleh brand image menunjukan nilai koefisien beta sebesar 0,150 dan menghasilkan pengaruh total sebesar 0,487

Perhitungan peran brand image memediasi pengaruh promosi dengan keputusan pembelian yaitu:

$$
\mathrm{Sa} 2 \mathrm{~b}=\sqrt{\mathrm{a}^{2} \mathrm{Sb}^{2}+\mathrm{b}^{2} \mathrm{Sa}^{2}+\mathrm{Sa}^{2} \mathrm{Sb}^{2}}
$$

Keterangan:

$$
\begin{aligned}
& \mathrm{a}=0,412 \\
& \mathrm{Sa}=0,084 \\
& \mathrm{~b}=0,339 \\
& \mathrm{Sb}=0,078 \\
& \mathrm{Sa} 2 \mathrm{~b}=\sqrt{\mathrm{a}^{2} \mathrm{Sb}^{2}+\mathrm{b}^{2} \mathrm{Sa}^{2}+\mathrm{Sa}^{2} \mathrm{Sb}^{2}} \\
& \mathrm{Sa} 2 \mathrm{~b}=\sqrt{0,0010+0,0008+0,0000} \\
& =\sqrt{0,0019} \\
& =0,043434 \\
& \mathrm{Z}=\frac{a b}{S a 2 b} \text {. } \\
& =\frac{0,1397}{0,043434} \\
& =3,2156
\end{aligned}
$$

Berdasarkan hasil Uji Sobel dalam penelitian ini menunjukkan bahwa hasil tabulasi $Z=3,2156>1,96$ dengan tingkat signifikansi $0,000<0,05$ yang berarti variabel mediasi yakni brand image dinilai secara signifikansi mampu memediasi pengaruh promosi terhadap keputusan pembelian produk Smartphone Samsung Di Kota Denpasar.

Perhitungan peran brand image memediasi pengaruh harga dengan keputusan pembelian yaitu:

$$
\mathrm{Sa} 2 \mathrm{~b}=\sqrt{\mathrm{a}^{2} \mathrm{Sb}^{2}+\mathrm{b}^{2} \mathrm{Sa}^{2}+\mathrm{Sa}^{2} \mathrm{Sb}^{2}}
$$

Keterangan:

$$
\begin{aligned}
& \mathrm{a}=0,446 \\
& \mathrm{Sa}=0,083 \\
& \mathrm{~b}=0,339 \\
& \mathrm{Sb}=0,078 \\
& \mathrm{Sa} 2 \mathrm{~b}=\sqrt{\mathrm{a}^{2} \mathrm{Sb}^{2}+\mathrm{b}^{2} \mathrm{Sa}^{2}+\mathrm{Sa}^{2} \mathrm{Sb}^{2}} \\
& \mathrm{Sa} 2 \mathrm{~b}=\sqrt{0,0012+0,0008+0,0000} \\
& =\sqrt{0,0020} \\
& =0,0445028 \\
& \mathrm{Z}=\frac{a b}{\operatorname{Sa} 2 b}
\end{aligned}
$$




$$
\begin{aligned}
& =\frac{0,1512}{0,045028} \\
& =3,3444
\end{aligned}
$$

Berdasarkan hasil Uji Sobel dalam penelitian ini menunjukkan bahwa hasil tabulasi $\mathrm{Z}=3,3444>1,96$ dengan tingkat signifikansi $0,000<0,05$ yang berarti variabel mediasi yakni brand image dinilai secara signifikansi mampu memediasi pengaruh harga terhadap keputusan pembelian produk Smartphone Samsung Di Kota Denpasar.

Berdasarkan penelitian yang telah dilakukan dapat diketahui bahwa secara teoretis, penelitian ini mendukung beberapa teori yang telah ada sebelumnya. Penelitian ini diharapkan dapat menjadi suatu hal baru untuk penelitian yang berhubungan dengan variabel promosi, harga, brand image dan keputusan pembelian. Pengolahan data dilakukan dengan teknik analisis jalur (path analysis) untuk memperkirakan hubungan antara variabel-variabel yang telah ditetapkan sebelumnya berdasarkan teori.

Penelitian ini juga menggunakan uji sobel untuk menguji kekuatan pengaruh tidak langsung variabel promosi $\left(\mathrm{X}_{1}\right)$ dan harga $\left(\mathrm{X}_{2}\right)$ terhadap variabel brand image (M) melalui variabel keputusan Pembelian (Y). Hasil penelitian ini diharapkan dapat digunakan untuk memperkaya referensi yang berkaitan dengan promosi, harga, brand image dan keputusan pembelian.

Hasil penelitian ini digunakan sebagai masukan bagi pihak smartphone Samsung untuk dapat meningkatkan promosi dan harga produk sehingga nantinya dapat menciptakan brand image yang baik konsumen yang dapat meningkatkan keputusan pembelian konsumen untuk membeli produk smartphone Samsung. Strategi yang dapat dilakukan yaitu dengan memperhatikan masukan dari konsumen, membuat fitur baru yang dibutuhkan konsumennya agar semua kebutuhan konsumennya dapat terpenuhi.

\section{SIMPULAN}

Promosi berpengaruh positif signifikan terhadap Brand Image pada produk smartphone Samsung di Kota Denpasar. Jadi, semakin baik promosi produk smartphone Samsung di benak konsumen, maka akan semakin baik pula brand image yang dimiliki oleh produk smartphone samsung di Kota Denpasar.

Harga berpengaruh positif signifikan terhadap brand image pada produk smartphone Samsung di Kota Denpasar. Jadi semakin baik harga yang ditawarkan produk smartphone Samsung kepada konsumen, maka akan semakin baik pula brand image akan produk smartphone Samsung.

Brand image berpengaruh positif dan signifikan terhadap keputusan pembelian pada produk smartphone samsung di Kota Denpasa. Jadi semakin baik brand image yang dimiliki produk smartphone samsung maka akan semakin tinggi pula keputusan pembelian konsumen terhadap produk smartphone Samsung di Kota Denpasar.

Promosi berpengaruh positif signifikan terhadap keputusan pembelian konsumen pada produk smartphone Samsung di Kota Denpasar. Jadi semakin baik promosi yang dilakukan produk smartphone Samsung, maka akan semakin 
tinggi pula keputusan pembelian konsumen terhadap produk smartphone Samsung di Kota Denpasar.

Harga berpengaruh positif signifikan terhadap keputusan pembelian konsumen pada produk smartphone Samsung di Kota Denpasar. Jadi semakin baik harga yang ditawarkan produk smartphone Samsung kepada konsumen. , maka akan semakin tinggi pula keputusan pembelian konsumen terhadap produk smartphone Samsung di Kota Denpasar. Promosi secara signifikan memediasi pengaruh brand image terhadap keputusan pembelian pada produk smartphone Samsung di Kota Denpasar. Artinya, promosi yang dimiliki oleh produk smartphone Samsung mampu memperkuat pengaruh brand image produk smartpone samsung terhadap keputusan pembelian produk smartphone Samsung di Kota Denpasar.

Harga secara signifikan memediasi pengaruh brand image terhadap keputusan pembelian pada produk smartphone Samsung di Kota Denpasar. Artinya, harga yang dimiliki oleh produk smartphone Samsungmampu memperkuat brand image produk smartphone samsung terhadap keputusan pembelian produk smartphone samsung di Kota Denpasar.

Sebaiknya manajemen smartphone samsung lebih meningkatkan promosi melalui penyelanggaraan pameran pada event-event tertentu atau pada pusat-pusat perbelanjaan sehingga membuat konsumen tertarik dan lebih mengenal langsung produk yang dimiliki oleh Smartphone Samsung. Sehingga diharapkan terjadinya keputusan pembelian. Dari segi harga diharapkan Smartphone Samsung lebih sering memberikan potongan harga atau discount kepada konsumen sehingga mampu menarik minat beli konsumen.

Pihak manajemen smartphone samsung sebaiknya memberikan informasi lebih gencar tentang manfaat dari produk smartphone Samsung. Sehingga dapat mewujudkan brand image yang lebih baik.

Diharapkan manajemen smartphone samsung tetap melakukan promosi dan menjaga kualitas produk karena WOM dan E-WOM dari satu konsumen ke konsumen lainnya akan mempengaruhi brand image serta keputusan pembelian konsumen terhadap produk smartphone samsung.

Penelitian di masa yang akan datang perlu mempertimbangkan penggunaan variabel lain yang dapat mempengaruhi keputusan pembelian produk misalnya seperti kualitias produk, kualitas pelayanan, dan lain sebagainya sehingga mampu menganalisis lebih lanjut faktor-faktor yang memiliki pengaruh terhadap keputusan pembelian.

Bagi peneliti selanjutnya diharapkan dapat memperluas cakupan wilayah penelitian misalnya dengan mengambillokasi di seluruh bali atau wilayah selain Kota Denpasar atau Indonesia.

\section{REFERENSI}

Amanah, dita. (2011). Pengaruh Promosi Dan Brand Image (Citra Produk) Terhadap Loyalitas Pembelian Produk Pepsodent Di Ramayana Plaza Jalan Aksara Medan. Jurnal Keuangan dan Bisnis. 3 (3). pp : 221-233 
Dahmiri. (2009). Pengaruh Bauran Penjualan Eceran (Retailing Mix) Terhadap Citra Department Store (Studi pada Ramayana Deparment Store Kota Jambi). Jurnal Manajemen Pemasaran Modern, 1(1), h. 2085-0972.

Dharma, N.P.S.A. dan Sukaatmadja, I.P.G. (2015). Pengaruh Citra Merek, Kesadaran Merek, dan Kualitas Produk Terhadap Keputusan Membeli Produk Apple. E-Jurnal Manajemen Unud, 4 (10), hal.3228-3255.

Evelina, Nela, Handoyo Dw, Sari Listyorini. (2012). Pengaruh Citra Merek, Kualitas Produk, Harga, Dan Promosi Terhadap Keputusan Pembelian Kartu Perdana Telkomflexi. Journal Of Social And Politic. 1 (1). Pp : 1-11

Fianto, A. Y. (2014). The Influence of Brand Image on Purchase Behaviour Through Brand Trust. Business Management and Strategy, 5(2), pp:59-76.

Fristiana, Dessy Amelia. (2012). Pengaruh Citra Merek dan Harga terhadap Keputusan Pembelianpada Ramai Swalayan Peterongan Semarang. Jurnal Ilmu Administrasi Bisnis, 1(1), h. 1-9.

Ghanimata, F., dan Kamal, M, (2012). Analisis Pengaruh Harga, Kualitas Produk, dan Lokasi terhadap Keputusan Pembelian (Studi pada Pembeli Produk Bandeng Juwana Elrina Semarang).Diponegoro Journal of Management, 1(2), h. 1-10.

Hasan,Ali. (2013). Marketing dan Kasus-Kasus Pilihan. Yogyakarta: CAPS (Center For Academic Publishing Service).

Kotler, P. and Keller, K. L. (2009). Manajemen Pemasaran. Edisi 12. Jilid 1. Alih bahasa: Benyamin Molan. Jakarta: Indek.

Lestari, Berta. (2012). Pengaruh Bauran Promosi Terhadap Hasil Penjualan Pada Perusahaan Jasa Ekspedisi Muatan Kapal Laut (Emkl) Di Kota Banjarmasin. Jurnal Ilmu-ilmu Sosial. 4 (1). pp: 41-48.

Malik, M. E., Ghafoor, M.M., Iqbal, H. K., Ali, Q., Hunbal, H., Noman, M., et al. (2013). Impact of Brand Image and Advertisement on Consumer Buying Behavior. World Applied Sciemces Journal, 23(1), pp: 117-122.

Margiyanto. (2013). Analisis Pengaruh Citra Merek, Persepsi Harga, Kualitas Produk, dan Promosi Terhadap Keputusan Pembelian Blackberry Di Kota Semarang. Skripsi Fakultas Ekonomika Dan Bisnis Universitas Diponegoro Semarang.

Marnis, and Marzdina.(2010). Pengaruh Dimensi Produk and Promosi Terhadap Citra Merek (Brand Image) Rokok Lucky Strike di Kota Pekan Baru.Jurnal Fakultas Ekonomi Universitas Riau. 19(1): 1-14. 
Mendrofa, Yoseph Baniader. (2010). Effect of product Knowledge and Brand Image To Purchase Intention With HP Laptop Brand Price Discount As Variable Moderated In Surabaya. Journal Of Management.

Mongi, Lidya, Lisbeth Mananeke, dan Agusta Repi. (2013). Kualitas Produk, Strategi Promosi dan Harga Pengaruhnya terhadap Keputusan Pembelian Kartu Simpati Telkomsel di Kota Manado. Jurnal Riset Ekonomi, Manajemen, Bisnis dan Akuntansi, 1(4), h. 2336-2346.

Musay, Fransisca Paramitasari. (2013). Pengaruh Brand Image terhadap Keputusan Pembelian (Survei pada Konsumen KFC Kawi Malang). Jurnal Administrasi Bisnis, 3(2),h. 1-7.

Noerchoidah. (2013). Analisis Pengaruh Harga, Kualitas Produk dan Iklan Terhadap Brand Image dan Keputusan Pembelian Sepeda Motor Kawasaki. Jurnal Wiga, 3 (1): 48-60.

Purnamasari, S., dan Murwatiningsih, (2015). Brand Image sebagai Mediasi Pengaruh Promosi, Harga dan Sikap Konsumen terhadap Keputusan Pembelian Jamu Nyonya Meneer di Semarang Timur. Management Analysis Journal, 4(3), h. 265-272.

Ranto,D.W.P. (2014). Pengaruh Harga, Desain Produk, Kualitas Produk dan Citra Merek terhadap Keputusan Pembelian Konsumen pada Produk Ukm di Yogyakarta. Akademi Manajemen Administrasi YPK Yogyakarta. 5(2), h. 206-218.

Tjiptono, Fandy, Chandra Gregorius. (2005). Servise Quality, And Satisfaction. Penerbit Andi. Yogyakarta.

Utama, I Gusti Ngurah Kusuma Yudha. (2014). Faktor-Faktor Yang Mempengaruhi Konsumen Dalam Keputusan Pembelian Smartphone Blackberry Studi Kasus Kota Denpasar. E-Jurnal Manajemen Unud, 3 (3), h. 679-693.

Widianto, Eka Tomi (2009). Analisis Pengaruh Faktor-Faktor Marketing Mix Terhadap Keputusan Pembelian Kompor Geni di Sidoharjo, Jurnal Manajemen Fakultas Ekonomi Universitas Pembangunan Nasional "Veteran" Jawa Timur. 